\title{
Strategic Planning for Systems \& Information Technology of XYZ Hospital Using Ward and Peppard Method
}

\author{
I Made Candra Girinata ${ }^{1}$ and Erma Suryani ${ }^{1}$
}

\begin{abstract}
XYZ Hospital is one of the busiest private hospitals in Badung, Bali which has implemented systems and information technology handled by its IT division staff. However, the implementation of systems and information technology has not been equipped with strategic planning so that it has not been directed and aligned with the company's business strategy, only based on demand. The impacts of there's no strategic planning systems and information technology is the companies are difficult to invest appropriately based on system requirements and information technology that can support the company's business strategy. Increasing the competitive advantage of utilizing systems and information technology still not optimal because the development of IS / IT lack directional and appropriate. Therefore, to overcome the problems, in this research is making strategic planning of systems and information technology of XYZ hospital, which carried out with Ward and Peppard method which serves to produce an IS /IT strategic plan that can help the company to run their process business more effectively as well as add its business value. The analysis techniques used are Value Chain, PEST, Porter 's Five Forces, SWOT, BSC, CSF, gap analysis and Mc Farlan's Strategic Grid. From the results of the analysis of the current condition of the company shows that XYZ Hospital is in the position of quadrant 1 which indicates the company should be focused on an aggressive strategy where reduce weaknesses and avoid threats to get maximum benefit. The recommendations for future application portfolios obtained are three applications in the high potential quadrant, one application in the strategic quadrant and two applications in the key operational quadrant. The results of this study aim to provide an overview to management in making decisions relating to investment, implementation and management policies of IS / IT that can support the company's vision and mission.
\end{abstract}

Keywords-Strategic Planning, Information Systems, Ward \& Peppard, Hospital.

\section{INTRODUCTION}

The utilization of systems and information technology can have good benefits for the company. Good IT alignment in a company can help organizations to compete with their competitor [1]. According to the regulation of Indonesian Ministry of Health concerning hospital states that hospital is health care institutions for the community

${ }^{1}$ I Made Candra Girinata and Erma Suryani are with Department of Management Technology, Institut Teknologi Sepuluh Nopember, Indonesia. Email: ghirinata@gmail.com; erma.suryani@gmail.com. with their own characteristics that are influenced by the development of advances in technology, health science and socio-economic life of the community who must be able to improve services quality and affordable for the community in order to realize the highest degree of health, therefore to create a more quality service requires a serious effort in utilizing the system and information technology in hospitals in order to can help their process business run effectively and efficiently.

Today, competition between government hospitals and private hospitals in gaining market share is very tight. This triggers both parties to compete with each other to provide the best health services for consumers, including by utilizing systems and information technology as one of the strategic supporting tools to increase competitive advantage. XYZ Hospital is one of the busiest private hospitals in the Badung region, Bali. As a supporting tool for its business processes, XYZ Hospital has implemented a system and information technology that is handled directly by IT division staff. However, the application of systems and information technology at XYZ Hospital has not been equipped with strategic planning so that it has not been directed and aligned with the company's business strategy, its nature is only on demand. The impact of the absence of strategic planning of system and information technology from a company is difficult to invest appropriately based on the needs of system and information technology that can support the company's business strategy. Increasing the competitive advantage of utilizing systems and information technology is also lacking due to the lack of directional and appropriate improvement of IS / IT.

Moreover, strategic planning also helps a company to plan company activities based on human resources potential so as to be able to guide business process activities in meeting environmental challenges and achieving competitive advantages that enable organizations to survive and achieve their goals in the long term [2].

Based on the description above, strategic planning of system and information technology is needed at XYZ Hospital. The method that have been relatively widely used for strategic planning systems and information technology is John Ward and Joe Peppard. Some researchers such as Christianti \& Harisno [3] with the research title "Information System Strategic Planning in PT XYZ" use the Ward and Peppard method that produces an application 
portfolio along with IS / IT recommendations for the future. The next study was carried out by Hannesto \& Surya [4] with the title.

"Information System Strategic Planning in XYZ Foundation at Learning and Development Division", the results of research using the Ward and Peppard method were an application portfolio for organizations that contained information system strategy planning needs. Another study that also uses the Ward and Peppard method is the "Strategic Information System for the Implementation of Information Technology at Polytechnic" API in Yogyakarta ", the research conducted by Budiyanto \& Setyohadi [5] resulted in several recommendations for information systems and management recommendations of SI / IT for the future of Yogyakarta API Polytechnic.

Judging from some of those studies it is known that the method of John Ward and Joe Peppard is very good to make strategic planning of system and information technology. Based on the background described above, in this study, the authors choose to use John Ward and Joe Peppard method to make Strategic Planning of system and information technology at XYZ Hospital

\section{LITERATURE REVIEW}

There are several stages carried out in this study including:

\section{A. Early Stage}

The stage of determining background, problem formulation, research objectives, the benefits of research related to IS / IT strategic planning at XYZ Hospital. In the background section discussed the problems that occur in IS / IT at XYZ Hospital so that it can identify problems well.

\section{B. Data Collection}

In conducting this research, data collection is needed to conduct strategic planning research at XYZ Hospital that using Ward \& Peppard method. Collecting data and information related to IS / IT strategic planning at XYZ Hospital are done by means of literature studies, interviews, observation, study of company documents.

\section{Analysis Process of Current Conditions}

The current condition analysis process is carried out to understand and analyze current conditions in terms of internal and external business as well as in terms of internal and external IS / IT companies. The steps used to analyze current conditions are as follows:

\section{1) Internal Business Analysis}

The internal business environment analysis in this study refers to the conditions and business situation of $\mathrm{XYZ}$ Hospital. The analytical method used to understand the internal environmental conditions of XYZ Hospital can be divided into 2, namely the analysis of the company's business strategy and value chain analysis.
- Analysis of the company's business strategy is done to find out or map the direction and purpose (vision, mission and other objectives) of the XYZ Hospital company. The result of this analysis is the opportunity to obtain business priority processes and business needs that lead to SI demand.

TABLE 1.

BUSINESS STRATEGY ANALYSIS RESULTS

\begin{tabular}{ll}
\hline \hline Code & \multicolumn{1}{c}{ Analysis Results } \\
\hline SB1 & Cooperating to strengthen its existence \\
SB2 & Providing qualityservices \\
SB3 & Strategic hospital location \\
SB4 & Give discounts and merchandise tooutpatient and hospitalization \\
SB5 & Providing training tomedicaland non-medical employees \\
\hline \hline
\end{tabular}

- Value chain analysis is used to map activities or activities involved in business processes that occur within the company's internal environment, so that the need for information will emerge. Mapping all business activities can divide into 2 part namely, supporting and primary activities.

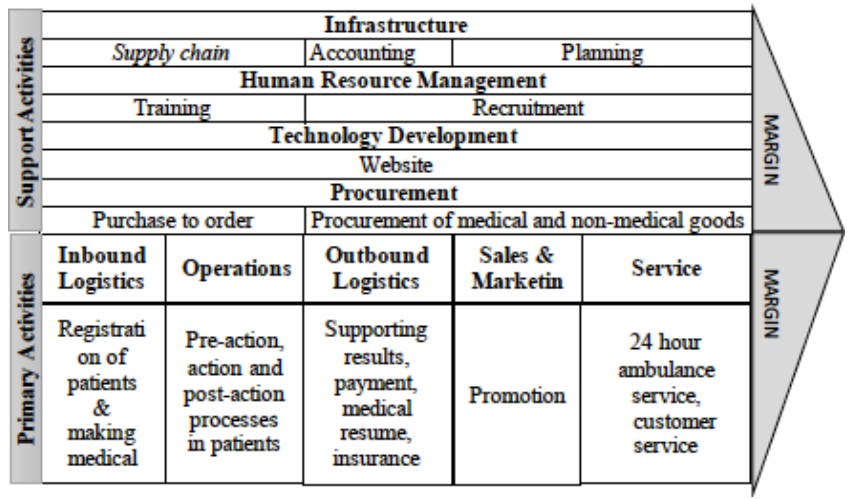

Figure 1. Value Chain

From the results of the value chain analysis, the results obtained are as shown in Table 2.

picture

TABLE 2.

VALUE Chain ANALYSIS RESUlts.

\begin{tabular}{|c|c|}
\hline Code & Analysis Results \\
\hline $\mathrm{VC} 1$ & $\begin{array}{l}\text { Receive patients with various types of health insurance } \\
\text { both internationally and nationally. }\end{array}$ \\
\hline $\mathrm{VC} 2$ & $\begin{array}{l}\text { A good marketing strategy by doing promotions on social } \\
\text { media and participating in international and local events. }\end{array}$ \\
\hline $\mathrm{VC} 3$ & Skilled human resource recruitment. \\
\hline $\mathrm{VC} 4$ & Utilization of website technology that is not optimal. \\
\hline
\end{tabular}

2) External Business Analysis

The external business environment analysis in this study refers to the environmental conditions of XYZ Hospital which are influenced by factors beyond the control of XYZ Hospital but it is possible to make an impact on policies and decisions taken by XYZ Hospital. The purpose of this stage is to know and understand the opportunities and 
threats that may be faced by XYZ Hospital. The analysis method used to understand the external environmental conditions of XYZ Hospital can be divided into 2, namely PEST analysis and Porter's five forces analysis.

- PEST analysis is used to understand the external environmental conditions of XYZ Hospital in general through four aspects, namely politics, economics, social and technology that can affect the company's business. The results of the analysis will be used to determine the business strategy that will be carried out by the company.

TABLE 3.

PEST ANALYSIS RESULTS.

\begin{tabular}{cl}
\hline \hline Code & \multicolumn{1}{c}{ Analysis Results } \\
\hline PE1 & $\begin{array}{l}\text { Government policy regarding medical equipment import tax, } \\
\text { the government should not overburden import taxes on medical } \\
\text { \& surgical equipment. }\end{array}$ \\
PE2 & $\begin{array}{l}\text { Support Indonesian government in achieving Universal Health } \\
\text { Coverage (UHC) or comprehensive health coverage for entire } \\
\text { people by serving participants of health BPJS. } \\
\text { PE3 }\end{array}$ \\
PE4 stability of rupiah value against dollar value will greatly \\
affect the purchase of medical devices.
\end{tabular}

- Porter's five forces analysis is used to determine the strengths and threats posed by XYZ Hospital in the industrial world. In addition, Porter's five forces analysis is used to analyze the conditions of competition that occur. This analysis is formed from several factors, including: threat of new entrants, threat of substitutes, bargaining power of customers, bargaining power of suppliers and competitive rivalry.

TABLE 4.

PORTER'S FIVE FORCES ANALYSIS RESULTS.

\begin{tabular}{cl}
\hline \hline Code & \multicolumn{1}{c}{ Analysis Results } \\
\hline PF1 & The threat of new entrants of XYZ Hospital is still very low. \\
PF2 & $\begin{array}{l}\text { Product differentiation by providing the best services and } \\
\text { facilities for patients. }\end{array}$ \\
PF3 & $\begin{array}{l}\text { There are many traditional medicine clinics that offer health } \\
\text { services at low prices. }\end{array}$ \\
PF4 & $\begin{array}{l}\text { Obtained medical supplies and medical devices from various } \\
\text { suppliers. }\end{array}$ \\
PF5 & Compete with private and state hospitals. \\
\hline \hline
\end{tabular}

\section{3) Internal IS / IT Analysis}

Analysis of internal IS / IT is an analysis that covers current condition of IS / IT at XYZ Hospital, that includes several parts including analysis of resources, skills, IT infrastructure. Of the three sections, the reviewed aspect discusses how resources, employee skills to understand and operate IT infrastructure and how the condition of IS / IT infrastructure.

TABLE 5 .

INTERNAL IS/IT ANALYSIS

\begin{tabular}{cl}
\hline \hline Code & \multicolumn{1}{c}{ Analysis Results } \\
\hline IS1 & $\begin{array}{l}\text { The competencies or skills of IS/IT employees at XYZ } \\
\text { Hospital especially at the manager level are still not optimal } \\
\text { in terms of carrying out IS / IT development planning. }\end{array}$ \\
IS2 & The IS/IT management policy is still not going well. \\
IS3 & Quite a lot of data collection is done manually. \\
IS4 & There is no long-term planning to develop the system and \\
& information technology. \\
IS5 & There is no integration between applications. \\
\hline \hline 4) External IS /IT Analysis
\end{tabular}

External IS / IT Analysis refers to the analysis of trends and opportunities of IS / IT that can be used for XYZ Hospital.

\begin{tabular}{ll} 
& \multicolumn{2}{c}{ TABLE 6. EXTERNAL IS/IT ANALYSIS. } \\
\hline \hline Code & \multicolumn{1}{c}{ Analysis Results } \\
\hline ES1 & XYZ hospital can utilize trends of technology such as \\
& Booking Online, Cloud Computing, Electronic Nursing \\
& Record System (ENRS), Computer Provider Order Entry \\
& (CPOE) and Medical Artificial Intelligence Technology. \\
\hline \hline
\end{tabular}

\section{Analysis Process of Future Conditions}

Analysis process of future conditions is carried out to understand and analyze future conditions related to business needs and company IS / IT. The methods used to analyze future conditions are as follows: SWOT, Balanced Scorecard (BSC), and Critical success factor (CSF).

1) $\mathrm{SWOT}$

SWOT analysis is carried out by dividing into two parts, namely internal and external strategy factors. The Internal Factor Analysis Summary (IFAS) section contains the strengths and weaknesses of XYZ Hospital obtained from the results of the analysis of the internal and external business environment and SI / IT while the External Factor Analysis Summary (EFAS) section contains the threats and opportunities of XYZ Hospital obtained from the analysis of the internal and external business environment and IS / IT. Then fill the weight values for each IFAS and EFAS from 1 to 5, where the smaller the value is not important for the respondent and the greater the value it means is very important for the respondent. After that, do the calculation to get the average weight of IFAS and EFAS where the value of the weight starts from 0,000 to 1,000 where the higher the value of the weighting, the more important and vice versa. When the results of the average weight of IFAS and EFAS have obtained, the next is calculating the score. The formula used to obtain scores from IFAS and EFAS is the average weight multiplied by the rating. Determination of rating values 1 to 4 was obtained based on observations of researchers on the condition of the company at that time. In giving rating values there are differences between variables positive and negative. Variables belonging to the 
The $1^{\text {st }}$ International Conference on Business and Management of Technology (IConBMT)

August 3rd 2019, Institut Teknologi Sepuluh Nopember, Surabaya, Indonesia

category of strength or variables that are positive, the greater the rating value, the greater the strength, while the variables belonging to the category of weakness or variable are negative, giving a rating value is inversely proportional to the positive variable the smaller the value the greater also its weaknesses. The next step is to form a SWOT diagram to determine the condition of the company obtained from the total IFAS \& EFAS weighting score.

The final result of this analysis is a SWOT matrix that describes four sets of strategic alternatives. At this stage the SWOT matrix is used to find out what alternative strategies can be applied to XYZ Hospital. Based on the results obtained where the coordinate $\mathrm{X}=1.69085$ and coordinate $\mathrm{Y}=0.10556$. We can see in Figure 2. that the position of $\mathrm{XYZ}$ Hospital is in quadrant I, this quadrant indicates the company has strength and opportunity. The alternative strategy that can be applied is an aggressive strategy where XYZ Hospital is in a very good situation to take advantage of opportunities, reduce weaknesses and avoid threats so as to enable XYZ Hospital to expand and increase growth to get maximum benefit.

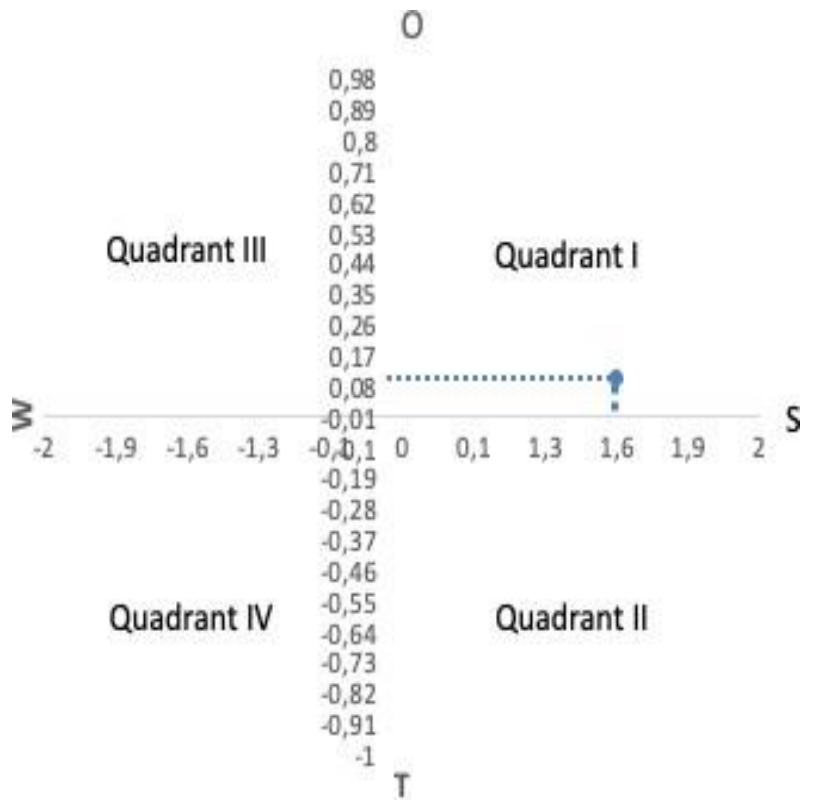

Figure 2. SWOT Matrix.

2) $B S C$

Balanced Scorecard is used to measure the performance of IS/IT seen from four perspectives consisting of financial perspective, customer perspective, internal business process perspective, growth and learning perspective which will later produce deep and integrated strategic goals. The results of this analysis are in the form of target business information needs that can be used as performance measurement tools. Indicators in each balanced scorecard perspective are obtained from various findings that are in accordance with the company's vision and mission based on the results of observations or questionnaires. To be able to see the strategy map design can be seen in Figure 3.

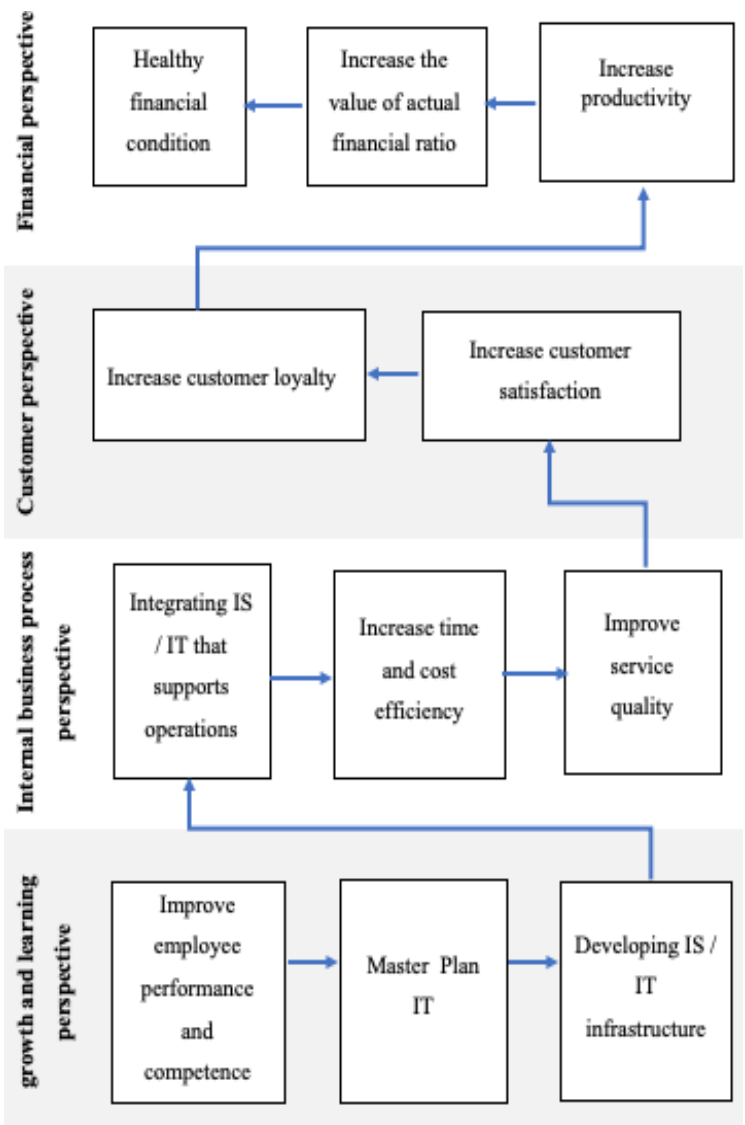

Figure 3. Strategy Map.

This analysis is used to find out objective key areas or success factors of XYZ Hospital in achieving its objectives. CSF analysis will be very useful when used in line with value chain analysis to find out the most critical processes so that it can provide a focus on the right activities in achieving company goals. The combination of balanced scorecard analysis technique and critical success factor is necessary to identify information or important things needed by business needs, which are in the balanced scorecard results. The steps used to consolidate BSC with CSF include:

1. Determine business needs from the results of BSC analysis.

2. Make a CSF analysis based on data and information needs that match business needs.

3. Determine the size of results obtained from business needs and CSF

4. Describe an activity to meet business needs and CSF.

The following is an example of consolidation results between BSC and CSF analysis for healthy financial condition business need: 
The $1^{\text {st }}$ International Conference on Business and Management of Technology (IConBMT) August 3rd 2019, Institut Teknologi Sepuluh Nopember, Surabaya, Indonesia

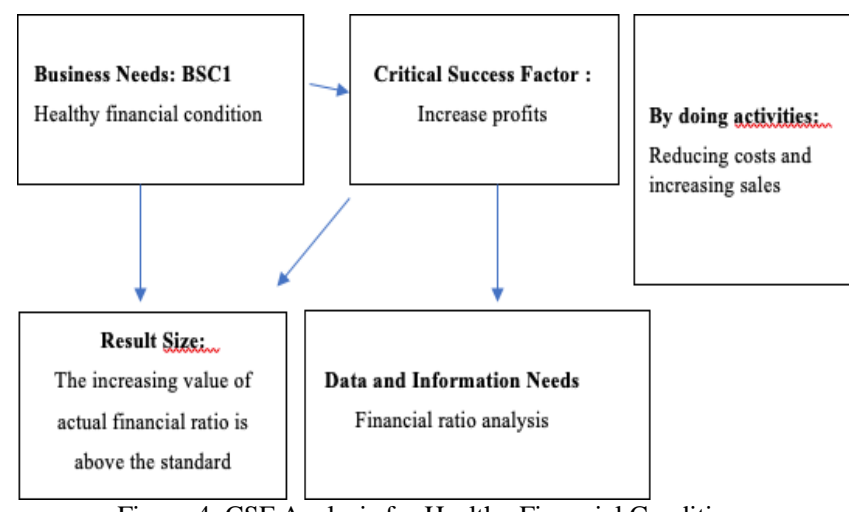

Figure 4. CSF Analysis for Healthy Financial Condition.

\section{3) Gap analysis}

Gap analysis is useful for knowing current conditions and what actions should be taken in the future, based on current business information needs and the capabilities of XYZ Hospital's IS / IT resources. The output of this analysis technique produces conclusions in the form of an action that must be taken by the XYZ Hospital so that it can achieve its potential performance. There are several types of actions used in the gap analysis technique including new system, replace, upgrade, retire, continue as-is.

\section{a. IS Gap}

At this stage, the information system gap analysis process is carried out to find out the gaps that occur between the potential business needs and the needs of IS. The results obtained in the information system gap analysis process are expected to provide appropriate decisions or actions in determining investment priorities and the development of the SI needs of the XYZ Hospital.

b. IT Gap

The information technology gap analysis discusses the gap between XYZ Hospital's IT infrastructure and IT human resource. To find out the results of IT gap analysis can be seen in Table 8 while the results of IT HR gap analysis can be seen in Table 9.

c. IS / IT Management Gap

Analysis of IS / IT management gap relating to policies in the implementation and management of existing systems and information technology in the company, thus supporting the results of recommendations for SI business strategies with the results of TI strategic recommendations. For more details see Table 10.

TABLE 7.

INFORMATION SYSTEM GAP ANALYSIS

\begin{tabular}{|c|c|c|c|c|c|}
\hline Code & $\begin{array}{l}\text { Bisnis Needs } \\
\text { Potential }\end{array}$ & $\begin{array}{l}\text { Current } \\
\text { condition }\end{array}$ & Action & IS/IT Management Needs & Reason \\
\hline$B S C 1$ & $\begin{array}{l}\text { Healthy financial } \\
\text { condition }\end{array}$ & & & & \\
\hline$B S C 2$ & $\begin{array}{l}\text { Increase the value } \\
\text { of the actual } \\
\text { financial ratio }\end{array}$ & Available & Upgrade & Financial system & $\begin{array}{l}\text { The current system does not yet have a complete } \\
\text { module so that Microsoft Excel applicatio } \mathrm{n} \text { is used to } \\
\text { create financial }\end{array}$ \\
\hline$B S C 3$ & $\begin{array}{l}\text { Increase } \\
\text { productivity }\end{array}$ & & & & \\
\hline$B S C 4$ & $\begin{array}{l}\text { Increase customer } \\
\text { loyalty }\end{array}$ & N/A & New System & Customer loyalty index system & There is no system that can measure customer loyalty. \\
\hline BSC 5 & $\begin{array}{l}\text { Increase customer } \\
\text { satisfacti on }\end{array}$ & N/A & New System & Customer satisfaction index system & $\begin{array}{l}\text { To find out the level of customer satisfactio } \mathrm{n} \text { from } \\
\text { service performance. }\end{array}$ \\
\hline$B S C 6$ & $\begin{array}{l}\text { Integrating IS / IT } \\
\text { that supports } \\
\text { operations }\end{array}$ & Available & Upgrade & SIM Hospital & $\begin{array}{l}\text { The SIM Hospital application that is used today can } \\
\text { still be said to be incomplete because there are several } \\
\text { systems or modules that need to be developed or } \\
\text { added in it, such as baby room modules, nutrition } \\
\text { instances and financial reports. }\end{array}$ \\
\hline$B S C 7$ & $\begin{array}{l}\text { Increase time and } \\
\text { cost efficiency }\end{array}$ & N/A & New system & IT Valuation system & $\begin{array}{l}\text { There needs to be a system that can measure the level } \\
\text { of time efficiency, costs and added value or IT } \\
\text { benefits for the company. }\end{array}$ \\
\hline$B S C 8$ & $\begin{array}{l}\text { Improve service } \\
\text { quality }\end{array}$ & N/A & New system & Service Quality Measurement & $\begin{array}{l}\text { There is no system that can measure the level of } \\
\text { service quality. }\end{array}$ \\
\hline
\end{tabular}

TABLE 8.

INFORMATION TECHNOLOGY GAP ANALYSIS.

\begin{tabular}{clccll}
\hline \hline Code & $\begin{array}{c}\text { Bisnis Needs } \\
\text { Potential }\end{array}$ & $\begin{array}{c}\text { Current } \\
\text { Condition }\end{array}$ & Action & IS / IT Management Needs & Reason \\
\hline BSC & $\begin{array}{l}\text { Developing IS / IT } \\
\text { infrastructure }\end{array}$ & N/A & New & $\begin{array}{l}\text { Booking Online, Cloud Computing, } \\
\text { Electronic Nursing Record System } \\
\text { system }), \text { Computer Provider Order Entry } \\
(\text { EPOE })\end{array}$ & $\begin{array}{l}\text { The rapid development of internet use and the } \\
\text { digital era must be utilized as well as possible by } \\
\text { companies to improve service quality and } \\
\text { competitive advantage }\end{array}$ \\
\hline \hline
\end{tabular}


The $1^{\text {st }}$ International Conference on Business and Management of Technology (IConBMT)

August 3rd 2019, Institut Teknologi Sepuluh Nopember, Surabaya, Indonesia

TABLE 9.

INFORMATION TECHNOLOGY HR GAP ANALYSIS

\begin{tabular}{|c|c|c|c|c|c|c|c|c|}
\hline Code & \multicolumn{2}{|c|}{ Bisnis Needs Potential } & \multicolumn{2}{|c|}{ Current Condition } & Action & \multicolumn{2}{|c|}{ IS / IT Management Needs } & Reason \\
\hline$B S C 9$ & $\begin{array}{l}\text { Improve Employee Perfor } \\
\text { and Competence }\end{array}$ & mance & Availa & & Continueas-is & \multicolumn{2}{|c|}{ Performance Appraisal } & $\begin{array}{l}\text { There is already KPI-based } \\
\text { performance appraisal }\end{array}$ \\
\hline \multicolumn{9}{|c|}{$\begin{array}{c}\text { TABLE } 10 . \\
\text { RESULTS OF IS / IT MANAGEMENT GAP ANALYSIS }\end{array}$} \\
\hline Code & Bisnis Needs Potential & Curre & t Condition & Acti & IS / IT M & Inagement Needs & & Reason \\
\hline BSC11 & Master Plan IT & N/A & & New Sy & Strat & gic Planning & $\begin{array}{l}\text { In order to } \\
\text { and potent } \\
\text { improve th }\end{array}$ & $\begin{array}{l}\text { able to empower the capacity } \\
\text { hat is owned so that it can } \\
\text { ality of service }\end{array}$ \\
\hline
\end{tabular}

\section{E. Strategy Formulation}

Strategy formulation is used to formulate future strategy of XYZ Hospital that obtained from the analysis that has been done in the previous stage. The outputs are generated from strategy formulations including SI business strategies, IT strategies and IS / IT management strategies.

- IS business strategy is an application recommendation needed by XYZ Hospital in the future to achieve its business goals.

- IT strategy is a strategic policy in the management of information technology and human resources IS / IT in XYZ Hospital that supports the strategic SI XYZ Hospital

- IS / IT management strategy is a strategy that contains policies that carried out by managementin implementing IS / IT in every business function to be consistent.

\section{F. Future Application Portfolio}

Future application portfolio is potential applications that fit the needs of the organization and comformable with the company's business strategy in form of McFarlan's Strategic Grid. There are several quadrants in the McFarlan's Strategic Grid method, which are: support, key operational, strategic, high potensial.

\section{RESULTS AND DISCUSSION}

\section{A. IS Business Strategy}

To obtain data and information needs, the information system needs that can be in the form of additions or development of applications in order to meet the business needs needed by XYZ Hospital. The following are recommendations for adding and developing applications to meet the business needs of XYZ Hospital:

1) Application additions

- Customer loyalty index system

Applications to increase customer loyalty, by measuring customer loyalty then determine where to focus efforts to improve service delivery.

- Customer satisfaction index system

Applications that can be used to determine differences in expectations and facts of the level of customer satisfaction or patients in using XYZ Hospital services.
- IT Valuation system

Application to measure the value of investment and implementation of company IS / IT by using two approaches, namely financial and non- financial costs so that the company can evaluate investment and implementation of IS / IT in accordance with the company's business objectives.

\section{- Service Quality Measurement}

Used as a tool to measure and evaluate for companies to understand and fulfill the needs and desires of consumers by analyzing consumer experience in using the services provided.

2) Application development

\section{- SIM Hospital}

The SIM Hospital application that is currently used must be further developed because for some systems or modules that are in it it is still incomplete, for example such as baby room modules, nutrition instalazi and financial reports. The development and completeness of these modules in the SIM Hospital Application is expected to support and even improve the company's operational performance.

- Financial system

The development of the module from the current financial application at XYZ Hospital is very necessary because the application still does not have a complete module so that the financial part of the XYZ Hospital is still using Microsoft Excel application which makes the financial division work impractical. The modules that need to be added are liquidity ratios, activity ratios, solvency ratios and profitability ratios.

\section{B. IT Strategy}

In this section discuss the things needed in implementation of STI based on the potential business needs that have been described in the previous analysis. Here are some recommendations for XYZ Hospital:

\section{1) Online Booking}

Use of online booking on the XYZ Hospital website with updates of web server for faster access, so that with booking online, patients can be more flexible and save waiting time during the registration process. 


\section{2) Cloud Computing}

The use of cloud computing is more flexible and facilitates internal communication so that employee mobilization can be streamlined.

3) Electronic Nursing Record System (ENRS)

Utilization of ENRS technology which is a digital form of nursing records containing all important information about status and patient intervention planned and provided by nurses. The goal is to streamline the time spent doing documentation, and the availability of information that is very easy and fast.

\section{4) Computer Provider Order Entry (CPOE)}

Utilization of CPOE technology that is used for a system of recording orders or medication orders from doctors. The aim is to increase the potential of nurse productivity and reduce medication errors.

\section{IS / IT Management Strategy}

IS / IT Management Strategy contains recommendations for future IS / IT management strategies for XYZ Hospital based on the analysis that has been done before, as for the recommendations given:

\section{- Strategic Plan}

Making strategic plan document is needed by XYZ Hospital to determine the right strategy and also serves as the right decision supporter in allocating resources or investment in IS / IT in order to achieve the desired business goals.

\section{Future Application Portfolio}

The results of the mapping of potential information system needs were obtained with three applications in the potential high quadrant, one application in the strategic quadrant and two applications in the key operational quadrant. To find out more clearly the mapping of future application portfolios based on the McFarlan Strategic Grid quadrant can be seen in Table 11.

TABLE 12.

STRATEGIC GRID OF FUTURE APPLICATION PORTFOLIO.

\begin{tabular}{|c|c|}
\hline Strategic & High Potential \\
\hline IT Valuation System* & Customer Loyalty Index System* \\
\hline \multirow[t]{8}{*}{ Help Desk $k^{\wedge}$} & Customer Satisfaction Index \\
\hline & System* \\
\hline & Service Quality Measurement* \\
\hline & $e K L A I M^{\wedge}$ \\
\hline & $v K L A I M^{\wedge}$ \\
\hline & $E-S K P^{\wedge}$ \\
\hline & Lupis $^{\wedge}$ \\
\hline & Apotek Online $e^{\wedge}$ \\
\hline Key Operational & Support \\
\hline Financial System” & Cha Applicationt $^{\wedge}$ \\
\hline Code Blue $e^{\wedge}$ & $H F I S^{\wedge}$ \\
\hline \multicolumn{2}{|l|}{ SIM Hospital" } \\
\hline Website Rumah Sakit XYZ^ & \\
\hline
\end{tabular}

Information:

*) Potential of application needs with additional status.

") Potential of application needs with development status.

^) Applications that are still in use today.

\section{CONCLUSION}

Based on the research that has done conclusions that can be drawn in the making of the system planning \& information technology of XYZ Hospital by using the ward \& peppard method can be divided into several points, namely:

- Specific finding for IT HR who in charge of being manager to be given training or seminars in order that they can understand the direction of planning, implementation and maintenance of existing information systems and technology at XYZ Hospital so that the investment in IS / IT can support the company's business needs both in productivity, efficiency and effectiveness, if possible it can become an enabler of competitive advantage.

- Referring to the results of the SWOT matrix that has obtained, where the coordinates $\mathrm{X}=1.69085$ and $\mathrm{Y}$ coordinates $=0.10556$ are in quadrant one, it shows that the strategy that should be focused by XYZ Hospital is an aggressive strategy where the XYZ Hospital is in a very good situation to take advantage of opportunities, reduce weaknesses and avoid threats so as to enable $\mathrm{XYZ}$ Hospital to expand and increase growth to get maximum benefit.

- There are several developments in information technology trends that can be utilized in supporting the business strategy of XYZ Hospital in the future. The information technology trends that can be utilized by XYZ Hospital in the future include booking online, cloud computing, electronic nursing record systems (ENRS), computer providers order entry (CPOE) and medical artificial intelligence technology.

- In accordance with the results of the formulation of the IS / IT management strategy at XYZ Hospital it is known that there needs to be an IT master plan to be able to empower the capacity and potential that is owned so that it can increase the coverage and quality of services.

- Obtained the results of the portfolio of future application which is divided into several parts including the recommended application with additional status, applications recommended with development status and applications that are still in use today with a total of 16 applications. The applications with additional status are customer loyalty index system, customer satisfaction index system, service quality measurement, IT valuation systems and applications with the development status of the financial system. 
The $1^{\text {st }}$ International Conference on Business and Management of Technology (IConBMT)

August 3rd 2019, Institut Teknologi Sepuluh Nopember, Surabaya, Indonesia

\section{REFERENCES}

[1] P. M. Malta and R. D. Sousa, "Looking for efective ways of achieving and sustaining Business-IT alignment," in 5th Iberian Conference on Information Systems and Technologies, 2010.

[2] M. Kataev and L. Bulysheva, "A system for strategic and tactical planning of industrial enterprise based on business processes," in Proceedings - 2nd International Conference on Enterprise Systems, ES 2014, 2014, pp. 33-35.

[3] N. Christianti and Harisno, "Information system strategic planning in PT XYZ," in Proceedings - 2017 International Conference on Applied Computer and Communication Technologies, ComCom 2017, 2017, pp. 1-8.
[4] R. Hannesto and M. M. Surya, "Information system strategic planning in XYZ foundation at learning and development division," in Proceedings of 2017 International Conference on Information Management and Technology, ICIMTech 2017, 2018, pp. 31-34.

[5] D. Budiyanto and D. B. Setyohadi, "Strategic information system plan for the implementation of information technology at Polytechnic 'API' Yogyakarta," in 2017 5th International Conference on Cyber and IT Service Management, CITSM 2017, 2017. 